\title{
Floristic similarity between adult and saplings strata of Caatinga hyperxerophilous woody vegetation - a Brazilian seasonally tropical dry forest
}

\section{Similitud florística entre estratos adultos y en regeneración de vegetación leñosa hiperxerófila de Caatinga - un bosque seco tropical brasileño}

\author{
Marcelo Silva de Lucena ${ }^{1}$ (D) $\bullet$ Alan Cauê de Holanda ${ }^{2}$ (D) $\bullet$ Allyson Rocha Alves ${ }^{2}$
}

Recibido: 21/01/2020Ａceptado: 24/03/2020Ｐublicado: 28/07/2020

\begin{abstract}
In the Caatinga, the maintenance of forest ecosystems depends on natural regeneration and several factors that can act in two ways: 1) provide the perpetuation of communities composed of few species that dominate the adult and saplings strata, resulting in floristic similarities; 2) provide local differentiation between adult and saplings strata. However, these relationships remain poorly understood, as it is not known whether the factors acting on a local scale favor the floristic similarity between the adult and saplings strata or if these patterns are found in conserved and anthropized areas. This work evaluated the floristic similarity between the adult and saplings strata of hyperxerophilous caatinga woody-shrubby vegetation in conserved and anthropized areas. In two areas of conserved and anthropized hyperxerophilous Caatinga, adult and saplings individuals were measured and floristic richness and qualitative floristic similarity were evaluated. The floristic similarity between the adult and saplings strata was statistically compared using the Chao-Sørensen index. In both sites, although there was a large number of species exclusive to the adult stratum, the Chao-Sørensen index indicates high floristic similarity between strata. The analysis of this behavior together with the assessment of community structure shows that few species can be responsible for the key processes that structure and control the main mechanisms of persistence of these ecosystems. This can be attributed to the existence of locally uniform conditions that can define the dominance of adapted species groups.
\end{abstract}

Key words: Semiarid vegetation, species richness and diversity, floristic composition, forest dynamics.

1. Postgraduate Program in Forest Science, Paulista State University “Júlio de Mesquita Filho”; Botucatu, Brazil; marceloslucena@hotmail.com

2. Department of Plant Science, Federal Rural University of Semiarid; Mossoró, Brazil; alan.holanda@ufersa.edu.br, allyson@ufersa.edu.br 


\section{Resumen}

En la Caatinga, el mantenimiento de los ecosistemas forestales depende de la regeneración natural y de factores que pueden actuar de dos maneras: 1) favoreciendo la perpetuación de comunidades compuestas de pocas especies que dominan los estratos adulto y regenerativo, lo que resulta en similitudes florísticas; 2) proporcionando diferenciación local entre los estratos adulto y en regeneración. Sin embargo, estas relaciones siguen siendo poco conocidas, ya que no se sabe si los factores que actúan a escala local favorecen la similitud florística entre los estratos adultos y en regeneración o si estos patrones se encuentran en áreas conservadas y antropizadas. Este estudio evaluó la similitud florística entre los estratos adulto y de regeneración de la vegetación arbóreo-arbustiva de Caatinga hiperxerófila en áreas conservadas y sometidos a intervenciones antrópicas. En áreas de Caatinga hiperxerófila (antropizada y conservada), se midieron individuos leñosos adultos y en regeneración y se evaluó la riqueza florística y la similitud florística cualitativa. La similitud florística entre los estratos adultos y en regeneración se comparó estadísticamente mediante el índice Chao-Sørensen. En ambos lugares, aunque hay una gran cantidad de especies exclusivas del estrato adulto, el índice Chao-Sørensen indicó una gran similitud florística entre los estratos. El análisis de este comportamiento junto con la evaluación de la estructura comunitaria demostró que pocas especies son responsables por los procesos-clave que estructuran y controlan los principales mecanismos de persistencia de estos ecosistemas. Esto puede deberse a la existencia de condiciones localmente uniformes que definen el dominio de grupos de especies adaptadas.

Palabras clave: Vegetación semiárida, riqueza y diversidad, composición florística, dinámica forestal.

\section{Introduction}

In Caatinga, a seasonally dry tropical forest occupying $912,529 \mathrm{~km}^{2}$ (predominantly in the semi-arid region of northeastern Brazil), the floristic and structural perpetuation of forest ecosystems is based on adaptations and interrelationships aimed at overcoming a strict environmental limitation imposed by irregular rainfall regimes and extensive droughts, which can be aggravated by human disturbances and interventions [1], [2], [3]. Maintaining woody vegetation cover depends critically on natural regeneration by recruiting saplings from locally established individuals [4], [5].
Given these conditions, although it is possible to postulate that the result of these processes is the existence of communities that share, at least locally, similarities in terms of floristic composition and structure, several factors, such as the floristic composition of neighboring fragments, the temporal and spatial phenological variation of seed production and seed dispersal syndromes, changes in environmental conditions that may favor or restrict certain species, patterns of diversity and floristic dominance or even past conditions of land use and occupation may contribute to local differentiation between taxon that make up the adult and saplings strata [5], [6], [7], [8].

However, factors with uniform spatial distribution on a local scale (e.g. precipitation regimes, typology and edaphic attributes or even the implications of anthropogenic disturbances) can contribute to communities with similar and homogeneous characteristics from a composition and structure standpoint [9], [10]. These communities can be made up of by a small number of dominant species, that are responsible for the key-processes that structure and control the main mechanisms of existence and persistence of these ecosystems [1], [11], [12], [13].

Thus, even different theoretical approaches and possibilities, assumptions about floristic divergences based on comparison of species richness or even qualitative similarity indices may lead to the understanding that there is, at least at the local level, floristic dissimilarity between adult components and saplings in Caatinga phytophysiognomies [14], [15], [16], [17], [18], [19]. However, the complex relationship between the adult and saplings stratum behavior, especially regarding the floristic similarities between these two components, remains poorly understood [20].

In the case of Caatinga woody vegetation, we still do not know completely: a) is there a floristic similarity between the saplings and adult strata? b) do similarities in floristic composition between saplings and adult strata exist only in conserved areas or does this behavior also occur in those areas that have been subjected to past anthropic disturbances? Thus, we hypothesized that: a) the qualitative differences in species composition between the adult and saplings strata result in floristic dissimilarity between them; b) floristic similarity should be seen only in areas subject to anthropic interventions, since we assume that these interventions can favor species adapted to the disturbances, which become dominant in the communities even after a considerable period of time.

The answers to these questions may be useful to provide insights for understanding the present and future dynamics of these communities, especially for the maintenance of floristic structure, richness, and floristic 
diversity under local specificities of the typologies of Caatinga, should be part of management and conservation strategies [1], [3], [5].

In view of the above, this paper aims to evaluate the floristic similarity between the strata and the regenerating tree-shrub woody vegetation of hyperxerophilous Caatinga in conserved areas and submitted to past anthropic interventions.

\section{Material and methods}

\section{Study areas}

The research was conducted in two locations situated in the "Depressão Sertaneja Setentrional" (for more details on the classification and characteristics of these ecoregions, see [2], [21]), in the semiarid zone of northeastern Brazil [21], where the Caatinga seasonally dry tropical forest predominates (figure 1).

The first study area is located in Assu National Forest (hereinafter referred to as "Flona de Assu"), in Assu State of Rio Grande do Norte - RN (latitude 05 $35^{\prime}$ '02.1" and longitude $36^{\circ} 56^{\prime} 41.9^{\prime \prime}$ west). The climate, according to Köppen's classification [22] is BSwh' type: dry, very hot and with seven to eight dry months. Average annual rainfall is $699 \mathrm{~mm}$ [23], annual average temperature of $28{ }^{\circ} \mathrm{C}$ and average annual relative humidity of $70 \%$ [24], [25]. Figure 2 shows the annual rainfall of the two areas studied for the period 1992-2013 [26].

The Caatinga vegetation is hyperxerophilous, with physiognomy composed of arboreal-shrub formations, with two distinct strata as to the composition and structure of the vegetation: 1) dense arboreal, with individuals that can reach up to $15 \mathrm{~m}$ in height; 2) sparse shrub, composing small patches, with individuals reaching 3 to $4 \mathrm{~m}$ in height [25] [27].

The soils have a complex spatial distribution, as in some places there are typically litholic, stony-looking soils, while in others there are clay soils. In some parts, where sedimentary processes of material accumulation predominate (usually at lower altitudes) there can be found sandy soils, which are extremely drained [24].

As for the conservation status of the Flona de Assu, there have been no records of direct anthropogenic interventions (agriculture, logging or grazing cattle) for at least 50 years. In the 1950s, localized experiments were conducted with native and exotic plant species. Subsequently, the site was intended for conservation and has been effectively protected since 2001 [24], [25].
The second study area was located at Seridó Ecological Station (hereinafter referred to as "Esec do Seridó"), in the State of Rio Grande do Norte - RN ( $06^{\circ} 35^{\text {' }}$ and $06^{\circ} 40^{\prime}$ ' S, $37^{\circ} 20$ 'and $37^{\circ} 9^{\prime}$ W). The climate is semi-arid BsW' $h$ ': dry, very hot and rainy season in summer [22]. According to Esec do Seridó weather station, the average annual temperature was $31^{\circ} \mathrm{C}$ and the relative humidity was $50 \%$. The average annual rainfall is $847 \mathrm{~mm}$ [23], ranging from $232 \mathrm{~mm}$ in 1998 up to approximately $1200 \mathrm{~mm}$ in 2002 (figure 2), with a concentrated rainy season from January to May [28], [29], [30]. Potential evapotranspiration is $2559 \mathrm{~mm}$ per year [31].

The vegetation is a hyperxerophilic type of Caatinga, with a sparse arboreal-shrub aspect, with small individuals (4-5 $\mathrm{m}$ average height and average diameter at breast height - DBH of $4.0 \mathrm{~cm}$ ) and seasonal herbaceous layer. In more preserved places and with better edaphic conditions, tree species of larger diameters and heights occur [32], [33], [34].

The soils, according to the Brazilian classification [35], are shallow chromic luvisols, consisting of poorly weathered mineral material, presence of nitric B or textural B horizon and high nutrient content. The base saturation is $83 \%$ [36]. There are also lithic neosols and vertisols [37].

The research area was under fallow after interventions carried out in 1989. That year, an experiment was performed with silvicultural interventions that ranged from selective cutting (individuals with base diameter> $8 \mathrm{~cm}$ were cut), to coppiced and coppiced with removal of the remaining stems and subsequent burning of residues harvest (twigs, branches and leaves) at the harvest site [38].

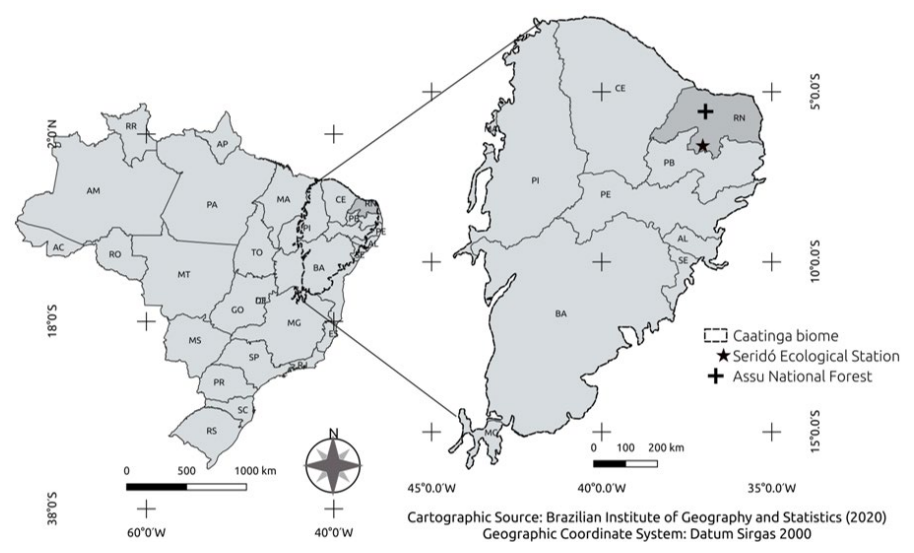

Figure 1. Brazil's map, indicating the location of the Caatinga biome zone and the study areas in the State of Rio Grande do Norte (RN).

Figura 1. Mapa de Brasil, que indica la ubicación de la zona del bioma de Caatinga y las áreas de estudio en el Estado de Rio Grande do Norte (RN). 


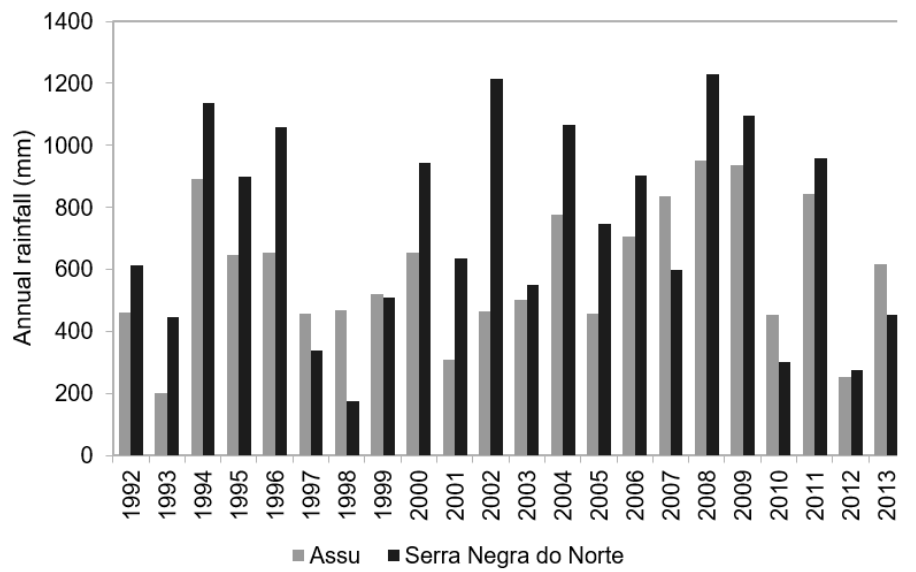

Figure 2. Precipitación anual de las áreas de estudio (período 19922013).

Figura 2.Annual rainfall of the areas studied (period 1992-2013).

\section{Data collection}

At both sites, phytosociological inventories consisted of measurements in two strata: adult trees and saplings. Adult individuals were those with circumference at breast height $(\mathrm{CBH}) \geq 6 \mathrm{~cm}$, measured at $1.30 \mathrm{~m}$ from the ground. The saplings were those with $\mathrm{CBH}<6 \mathrm{~cm}$ and height greater than $0.5 \mathrm{~m}$ [39].

In the Flona de Assu, 20 plots of $20 \times 20$ m were randomly measured in the adult stratum, while in the saplings inventory a subplot of $1 \mathrm{~m} \times 20 \mathrm{~m}$ was measured in each plot. In this area, the sample sufficiency was measured by the species-by-area curve method [40], and the collection curve was generated by the Statistical and Genetic Analysis System [41]. In the adult stratum, sample sufficiency was detected in the 10th plot, indicating that the 20 measured plots represent the local floristic composition. In natural regeneration, the curve stabilized at 14 th $\left(300 \mathrm{~m}^{2}\right)$. The total area sampled for regeneration was $400 \mathrm{~m}^{2}$.

At Esec do Seridó, 16 plots of $20 \times 20 \mathrm{~m}$ were systematically measured for the inventory of the adult stratum, while for the saplings a subplot of $5 \times 5 \mathrm{~m}$ was installed in the corner of each plot. The sample sufficiency, which covered $6400 \mathrm{~m}^{2}$, was similar to those recorded by [28], [30], [42], who found that $6000 \mathrm{~m}^{2}$ was sufficient to represent the woody floristic composition in an area without interventions at Esec do Seridó.

The circumference at breast height $(\mathrm{CBH})$ was performed using measuring tape with an accuracy of $0.5 \mathrm{~cm}$ and the total height with a $10 \mathrm{~cm}$ subdivided pole, with a total height of $5 \mathrm{~m}$. Phytosociological analysis were processed in the Mata Nativa Software [43].

\section{Identification of taxa}

In Flona de Assu, botanical material was collected from the individuals sampled and floristic comparisons were made with samples stored in the Herbarium "Dárdano de Andrade Lima" of the Federal Rural University of Semiarid (Universidade Federal Rural do Semiárido). The botanical classification system used was Angiosperm Phylogeny Group III [44].

At Esec do Seridó, the recognition of taxon was performed according to usual procedures of the Caatinga Forest Management Network - RMFC [39]. Thus, in the field, the common name of the individuals was annotated, together with the registration number of the individuals in each plot, allowing their subsequent location; at the same time, the dendrological evaluation of its characteristics was performed, aiming at the recognition of the taxon according to previous information recorded by the RMFC for this study area.

In both locations, based on prior recognition of each taxon, the spelling of the scientific names and classifiers of the species was updated according to the APG III system [44], according to the Flora of Brazil Species List [45].

\section{Quali-quantitative evaluation of the data}

To evaluate the floristic composition of the sampled fragments, species richness by area and stratum was accounted. Moreover, in each area, the similarity between the strata was qualitatively analyzed using Venn's diagrams, based on the presence and absence of the species. Additionally, the floristic similarity between the strata was statistically compared through of the Chao-Sørensen [46], with 95 \% confidence interval (Cl) using EstimateS Software 9.1.0 [47].

This is a quantitative index based on abundance and is suitable for comparing samples of different sizes [46]. The index of Chao-Sørensen ranges from 0 to 1 , where values greater than 0.5 indicate high similarity [20].

The floristic diversity in each stratum was evaluated by the Shannon-Weaver diversity index $\left(H^{\prime}\right)$ and ecological dominance was determined by the Pielou equability index ( $\mathrm{J}$ ') and Simpson Dominance index. Calculations were made in the PAST 3.25 Software [48].

Regarding the adult stratum, the following phytosociological parameters were evaluated: density, frequency, absolute dominance and importance value (IV). The IV \% was calculated by summing the values of relative density, relative frequency and relative dominance and dividing the result by three ((FR + DR + DoR) / 3) [49]. 
Table 1. List of families, species and number of individuals recorded in the adult and regenerating strata in the Flona de Assu, Rio Grande do Norte, Brazil

Cuadro 1. Lista de familias, especies y número de individuos registrados en el estrato adulto y en regeneración em la Flona de Assu, Rio Grande do Norte, Brasil

\begin{tabular}{|c|c|c|}
\hline anorion & Adult Number & Regeneration Number \\
\hline \multicolumn{3}{|l|}{ Anacardiaceae } \\
\hline Myracrodruon urundeuva Allemão & 23 & 0 \\
\hline \multicolumn{3}{|l|}{ Apocynaceae } \\
\hline Aspidosperma pyrifolium Mart. \& Zucc. & 58 & 0 \\
\hline \multicolumn{3}{|l|}{ Bignoniaceae } \\
\hline Handroanthus impetiginosus (Mart. ex DC.) Mattos & 878 & 128 \\
\hline \multicolumn{3}{|l|}{ Bixaceae } \\
\hline Cochlospermum vitifolium (Willd.) Spreng. & 16 & 2 \\
\hline \multicolumn{3}{|l|}{ Boraginaceae } \\
\hline Cordia oncocalyx Allemão & 47 & 0 \\
\hline Varronia sp. & 41 & 13 \\
\hline Cordia trichotoma (Vell.) Arráb. ex Steud. & 11 & 6 \\
\hline Cordia leucocephala Moric. & 0 & 5 \\
\hline \multicolumn{3}{|l|}{ Burseraceae } \\
\hline Commiphora leptophloeos (Mart.) J.B.Gillett & 28 & 1 \\
\hline \multicolumn{3}{|l|}{ Capparaceae } \\
\hline Cynophalla flexuosa (L.) J.Presl & 39 & 0 \\
\hline \multicolumn{3}{|l|}{ Combretaceae } \\
\hline Combretum leprosum Mart & 80 & 0 \\
\hline Thiloa sp. & 2 & 2 \\
\hline \multicolumn{3}{|l|}{ Erythroxylaceae } \\
\hline Erythroxylum nummularium Peyr. & 144 & 22 \\
\hline \multicolumn{3}{|l|}{ Euphorbiaceae } \\
\hline Croton blanchetianus Baill. & 60 & 11 \\
\hline \multicolumn{3}{|l|}{ Fabaceae } \\
\hline Bauhinia cheilantha (Bong.) Steud. & 199 & 32 \\
\hline Senegalia sp & 5 & 1 \\
\hline Poincianella pyramidalis (Tul.) L.P.Queiroz & 420 & 5 \\
\hline Piptadenia stipulacea (Benth.) Ducke & 140 & 13 \\
\hline Amburana cearensis (Allemão) A.C.Sm. & 28 & 0 \\
\hline Anadenanthera colubrina (Vell.) Brenan & 22 & 0 \\
\hline Mimosa tenuiflora (Willd.) Poir. & 8 & 0 \\
\hline \multicolumn{3}{|l|}{ Malvaceae } \\
\hline Pseudobombax marginatum (A.St.-Hil., Juss. \& Cambess.) & 22 & 0 \\
\hline \multicolumn{3}{|l|}{ Nyctaginaceae } \\
\hline Pisonia tomentosa Casar. & 11 & 0 \\
\hline \multicolumn{3}{|l|}{ Olacaceae } \\
\hline Ximenia americana L. & 122 & 0 \\
\hline \multicolumn{3}{|l|}{ Rhamnaceae } \\
\hline Ziziphus joazeiro Mart. & 1 & 0 \\
\hline Not identified & 3 & 68 \\
\hline Total & 2408 & 309 \\
\hline
\end{tabular}


The frequency and relative frequency data are not presented in the tables, as they were used only for the calculation of the importance value.

\section{Results and discussion}

In the adult stratum of Flona de Assu, 25 species belonging to 15 botanical families were recorded, comprising a total of 2408 individuals. In this area, in the saplings stratum, 309 individuals were inventoried, distributed in 12 species, comprising 11 botanical families. Two taxa were identified only at genus level and one was not identified (Table 1).

Although there is a high number of species exclusive to the adult stratum, the Chao-Sørensen index showed a high floristic similarity between strata at this location (Figure 3).

In the adult stratum of Esec do Seridó, 19 species belonging to eight botanical families were recorded, comprising 1326 individuals. In saplings, 109 individuals were sampled, distributed in 10 species and 6 families. Two taxa were not identified (Table 2).

The similarity measured by the Chao-Sørensen index was $0.99( \pm 0.003)$ and as found in the Flona de Assu, although there is a strong qualitative discrepancy between species richness composition, with most species restricted to the adult stratum, the calculated value of the index indicated a high floristic similarity between the adult and saplings strata (Figure 4).

The assumption about floristic divergences based on comparison of species richness or even on qualitative similarity indexes (e.g. Jaccard, which is based on the presence/absence of taxon) may lead to the understanding that there is, at least at the local level, dissimilarity floristic between the adult and saplings strata in Caatinga areas [14], [15], [16], [17], [18], [19].

Despite widespread application in ecological studies, qualitative similarity indices, such as Jaccard and Sørensen's, when calculated based on sample data, perform poorly as a measure of similarity between diverse communities that include a substantial fraction of rare species, because the sample data are assumed to be true and as complete representations of the species assemblage composition [46].

According to these authors, these measures often underestimating the true similarity between two (genuinely similar) clusters that contain rare species. This is because many rare species are absent from the samples, while the rare species that appear in one sample are generally different from the rare species that appear in another sample, even though all of them are currently present in both clusters. Similar problems arise from comparing two samples of substantially different sizes: simply because they contain few individuals or sample units, the small sample size may not capture species that appear in the samples with the largest area.

In short, the underestimation of similarity is due to the failure to account for "unseen" shared species (not captured by sampling). The Chao-Sørensen index, based on incidence (presence/absence) and abundance, from the sample data incorporates the effect of "unseen" shared species, promoting a substantial reduction in bias caused by sample size under traditional estimators, improving their inference power of similarity between communities for which a large proportion of species are absent from the samples [46].

In addition, generally, much research in Caatinga phytophysiognomies is based on comparing local variation of species richness in sites that have undergone anthropic interventions. There are indications that in anthropized fragments, even under conditions of chronic disturbance regimes, interventions may result in favorable conditions to the predominance of certain adapted species, with a strong negative impact on seedling and saplings diversity [5], [19] [50].

Important drivers of chronic disturbances, especially overgrazing and the continuous extraction of forest

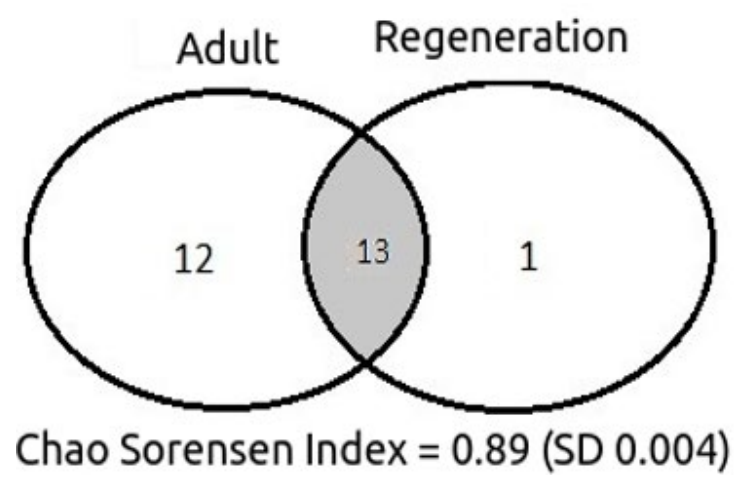

Figure 3. Venn's diagram showing shared and exclusive species for each stratum evaluated and calculated value of the Chao-Sorensen Index (+ - standard deviation) recorded in Flona de Assu, Rio Grande do Norte, Brazil.

Figura 3. Diagrama de Venn que muestra las especies compartidas y exclusivas para cada estrato evaluado y valor calculado del Índice Chao-Sorensen (+ - desviación estándar) registrado en la Flona de Assu, Rio Grande do Norte, Brasil 
Table 2. List of families, species and number of individuals recorded in the adult and regenerating strata at Esec do Seridó, Rio Grande do Norte, Brazil

Cuadro 2. Lista de familias, especies y número de individuos registrados en el estrato adulto y en regeneración en la Esec do Seridó, Rio Grande do Norte, Brasil

\begin{tabular}{|c|c|c|}
\hline \multirow{2}{*}{ Species } & Adult & Regeneration \\
\hline & Number & Number \\
\hline \multicolumn{3}{|l|}{ Apocynaceae } \\
\hline Aspidosperma pyrifolium Mart. \& Zucc. & 86 & 15 \\
\hline \multicolumn{3}{|l|}{ Bignoniaceae } \\
\hline Handroanthus impetiginosus (Mart. ex DC.) Mattos & 9 & 0 \\
\hline \multicolumn{3}{|l|}{ Burseraceae } \\
\hline Commiphora leptophloeos (Mart.) J.B.Gillett & 114 & 3 \\
\hline \multicolumn{3}{|l|}{ Capparaceae } \\
\hline Cynophalla flexuosa (L.) J.Presl & 1 & 0 \\
\hline \multicolumn{3}{|l|}{ Combretaceae } \\
\hline Combretum leprosum Mart & 31 & 8 \\
\hline \multicolumn{3}{|l|}{ Erythroxylaceae } \\
\hline Erythroxylum pungens O.E.Schulz & 36 & 15 \\
\hline \multicolumn{3}{|l|}{ Euphorbiaceae } \\
\hline Croton blanchetianus Baill. & 219 & 29 \\
\hline Cnidoscolus quercifolius Pohl & 18 & 1 \\
\hline Manihot caerulescens Pohl & 2 & 0 \\
\hline \multicolumn{3}{|l|}{ Fabaceae } \\
\hline Bauhinia cheilantha (Bong.) Steud. & 5 & 0 \\
\hline Libidibia ferrea (Mart. ex Tul.) L.P.Queiroz & 2 & 0 \\
\hline Senna macranthera (Collad.) Irwin et Barneby & 1 & 0 \\
\hline Mimosa tenuiflora (Willd.) Poir. & 117 & 8 \\
\hline Anadenanthera colubrina (Vell.) Brenan & 83 & 7 \\
\hline Piptadenia stipulacea (Benth.) Ducke & 35 & 3 \\
\hline Amburana cearensis (Allemão) A.C.Sm. & 1 & 0 \\
\hline Poincianella pyramidalis (Tul.) L.P.Queiroz & 559 & 20 \\
\hline Not identified 1 & 5 & 0 \\
\hline Not identified 2 & 2 & 0 \\
\hline Total & 1326 & 109 \\
\hline
\end{tabular}

products (especially firewood, piles and coal), may contribute to the gradual local extinction of species and alteration of vegetation structure, contributing to the floristic uniformity and simplification of communities [1]. Chronic anthropogenic disturbance may operate as an ecological filter by selecting functional trait values (e.g. low wood density), thereby altering the functional composition and diversity of plant assemblages. Some studies indicate that the effects of chronic anthropogenic disturbance were stronger in adult communities by negatively affecting functional richness, dispersion and their effect sizes. CAD also altered the functional composition of leaf mass per area, woody density and leaf area of adult assemblages [50].

However, the history of land use, the distribution and intensity of disturbances and the interaction between these two variables can determine, at the local level, the recovery processes and the floristic composition of the vegetation. This complex interaction can affect, among other things, organic matter content, soil nutrient content, remnant vegetation cover, availability and stock of seedlings available for recolonization [5], [20]. 
Table 3. Shannon-Weaver diversity index $\left(\mathrm{H}^{\prime}\right)$ and Pielou ( $\left.\mathrm{J}^{\prime}\right)$ equability recorded in the adult and regenerating strata in Assu National Forest and Seridó Ecological Station Rio Grande do Norte, Brazil

Cuadro 3 . Índice de diversidad de Shannon-Weaver $\left(\mathrm{H}^{\prime}\right)$ y la igualdad de Pielou (J') registrada en los estratos adultos y en regeneración en la Flona de Assu y la Esec do Seridó, Rio Grande do Norte, Brasil

\begin{tabular}{|ccccc|}
\hline Área & Adulto & \multicolumn{3}{c}{ Regeneração } \\
\hline & $H^{\prime}$ & $J^{\prime}$ & $H^{\prime}$ & J' \\
\hline Flona de Assu & 2.24 & 0.695 & 1.82 & 0.689 \\
\hline Esec do Seridó & 1.90 & 0.645 & 2.01 & 0.873 \\
\hline
\end{tabular}

It is possible that, throughout the succession process after disturbances, the interactions of these factors could result in irregular spatial distribution of physical and environmental conditions, creating niches for divergent communities in terms of floristic composition and may result in wide variation between the taxons that make up the adult and saplings strata on a local scale.

In assessing the floristic divergence of saplings between fragments submitted to anthropogenic interventions in an area of hyperxerophilous Caatinga, [19] stated that the differences found could be attributed not only to the creation of specific environmental conditions resulting from disturbances, but also to floristic composition of the fragments surrounding the evaluated areas, in terms of dominance and abundance (number and density of individuals), according to [7], [20]. Thus, new species that were locally recorded in recovering sites could come from areas under good conservation practices located nearby, which could favor the existence of floristically distinct communities at the local level.

However, the success of this strategy depends on the ability of species to reach the new site, which is directly related to dispersal syndromes and variation in seed production phenology [7], [19]. In dry tropical forests, such as Caatinga, anemochoric and autochoric dispersal patterns bring together conditions that can favor further dispersal, increasing the chance of colonization of new areas and local floristic diversification.

Anemochoric and autochoric seeds, which are most common in dry tropical forests, because they are small, light and less susceptible to dissection than other seed types (therefore, more likely to survive natural degradation) could be more likely to occur in new sites, contributing to the diversification of the local set of species [51].

In addition to the implications of interventions on similarity, local variations in environmental conditions, both in conserved areas and those that have undergone interventions, can create micro-sites that enable the emergence of diverse communities and possibly with considerable variation between phenological patterns, resulting in floristic dissimilarity between adults and saplings, as homogeneous environmental conditions can culminate in ecological dominance [7], [8].

Regarding phenological patterns as an important explanatory variable of local floristic divergence, discontinuity in flowering and fruiting or temporal variations of seed production may culminate in an alternation of the floristic composition of saplings [32], enable divergences in the floristic composition of the adult and regenerating components at local scale. However, disruption or alteration of seed production in response to unfavorable periods, such as droughts, may result in the dominance of species capable of withstanding these conditions, contributing to the simplification and floristic uniformity of communities.

Prolonged drought periods may favor increased similarity between strata of woody vegetation, as humidity is an

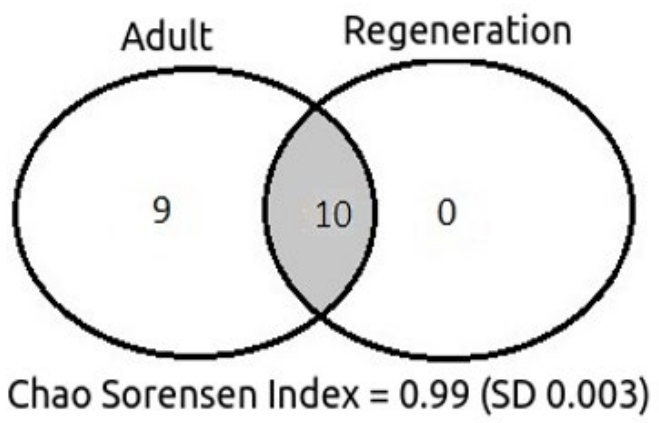

Figure 4. Venn's diagram showing the shared and exclusive species for each stratum evaluated and calculated value of the Chao-Sorensen Index (+ - standard deviation) recorded at Esec do Seridó, Rio Grande do Norte, Brazil

Figura 4 .Diagrama de Venn que muestra las especies compartidas y exclusivas para cada estrato evaluado y valor calculado del Índice Chao-Sorensen (+ - desviación estándar) registrado en la Esec do Seridó, Rio Grande do Norte, Brasil 
Table 4.Density, dominance and importance values recorded in the adult stratum in Flona de Assu and Esec do Seridó, Rio Grande do Norte, Brazil

Cuadro 4 .Valores de densidad, dominancia e valor de importância (VI\%) registrados en el estrato adulto en la Flona de Assu y la Esec do Seridó, Rio Grande do Norte, Brasil

\begin{tabular}{|c|c|c|c|c|c|}
\hline \multicolumn{6}{|c|}{ Flona de Assu } \\
\hline Species & DA & DR & DoA & DoR & VI (\%) \\
\hline P. pyramidalis & 525 & 17.44 & 4.57 & 42.08 & 22.51 \\
\hline H. impetiginosus & 1097 & 36.46 & 2.09 & 19.28 & 20.98 \\
\hline B. cheilantha & 248 & 8.26 & 0.17 & 1.61 & 5.96 \\
\hline A. pyrifolium & 73 & 2.41 & 0.69 & 6.31 & 5.31 \\
\hline P. stipulacea & 175 & 5.81 & 0.24 & 2.25 & 5.22 \\
\hline E. nummularia & 180 & 5,98 & 0.29 & 2.69 & 4.89 \\
\hline$X$. americana $L$. & 153 & 5.07 & 0.26 & 2.37 & 4.35 \\
\hline C. leptophloeos & 35 & 1.16 & 0.54 & 4.96 & 3.64 \\
\hline C.leprosum & 100 & 3.32 & 0.19 & 1.74 & 3.29 \\
\hline M. urundeuva & 29 & 0.96 & 0.34 & 3.63 & 3.13 \\
\hline A. cearensis & 35 & 1.16 & 0.52 & 4.76 & 2.91 \\
\hline C. flexuosa & 49 & 1.62 & 0.12 & 1.11 & 2.64 \\
\hline C. blanchetianus & 75 & 2.49 & 0.06 & 0.55 & 2.48 \\
\hline P.marginatum & 28 & 0.91 & 0.15 & 1.42 & 2.11 \\
\hline C. oncocalyx & 59 & 1.95 & 0.19 & 1.80 & 1.92 \\
\hline Varronia sp. & 51 & 1.70 & 0.05 & 0.41 & 1.90 \\
\hline A. colubrina & 28 & 0.91 & 0.06 & 0.69 & 1.60 \\
\hline C. vitifolium & 20 & 0.66 & 0.08 & 0.70 & 1.25 \\
\hline C. trichotoma & 14 & 0.46 & 0.03 & 0.27 & 1.18 \\
\hline P. tomentosa & 14 & 0.46 & 0.02 & 0.22 & 1.02 \\
\hline M. tenuiflora & 10 & 0.33 & 0.11 & 0.99 & 0.57 \\
\hline S. tenuiflora & 6 & 0.21 & 0.03 & 0.12 & 0.51 \\
\hline Not identified & 4 & 0.12 & 0.004 & 0.04 & 0.32 \\
\hline Thiloa sp. & 3 & 0.08 & 0.002 & 0.02 & 0.17 \\
\hline Z. joazeiro & 1 & 0.04 & 0.001 & 0.01 & 0.15 \\
\hline Total & 3010 & 100 & 10,6 & 100 & 100 \\
\hline \multicolumn{6}{|c|}{ Esec do Seridó } \\
\hline Espécie & DA & DR & DoA & DoR & $\mathrm{VI}(\%)$ \\
\hline P. pyramidalis & 873 & 42.16 & 3.52 & 43.59 & 32.34 \\
\hline M. tenuiflora & 183 & 8.82 & 1.20 & 14.85 & 11.18 \\
\hline C. leptophloeos & 178 & 8.6 & 1.26 & 15.57 & 11.11 \\
\hline C. blanchetianus & 342 & 16.5 & 0.46 & 5.72 & 10.7 \\
\hline A. colubrina & 129 & 6.26 & 0.59 & 7.28 & 7.57 \\
\hline A. pyrifolium & 134 & 6.49 & 0.32 & 3.98 & 6.77 \\
\hline P.stipulacea & 55 & 2.64 & 0.13 & 1.65 & 4.25 \\
\hline E. pungens & 56 & 2.71 & 0.08 & 1.01 & 3.83 \\
\hline C. quercifolius & 28 & 1.36 & 0.31 & 3.84 & 3.61 \\
\hline C. leprosum & 48 & 2.34 & 0.10 & 1.19 & 3.29 \\
\hline H. impetiginosus & 14 & 0.68 & 0.03 & 0.38 & 1.29 \\
\hline B. cheilantha & 8 & 0.38 & 0.01 & 0.15 & 0.88 \\
\hline Not identified 1 & 8 & 0.38 & 0.004 & 0.04 & 0.61 \\
\hline
\end{tabular}

Continúa en la siguiente página. 


\begin{tabular}{|c|c|c|c|c|c|}
\hline Espécie & DA & DR & DoA & DoR & VI (\%) \\
\hline L. ferrea & 3 & 0.15 & 0.02 & 0.23 & 0.60 \\
\hline Not identified 2 & 3 & 0.15 & 0.01 & 0.15 & 0.57 \\
\hline M.caerulescens & 3 & 0.15 & 0.01 & 0.10 & 0.55 \\
\hline C. flexuosa & 2 & 0.08 & 0.01 & 0.10 & 0.29 \\
\hline S. macranthera & 2 & 0.08 & 0.01 & 0.07 & 0.28 \\
\hline A. cearensis & 2 & 0.08 & 0.01 & 0.07 & 0.28 \\
\hline Total & 2071 & 100 & 8.08 & 100 & 100 \\
\hline
\end{tabular}

important filter for less rustic seedlings [51], [52], [18], especially for species with wide variation of phenological behavior and for those with low abundance of individuals in the adult stratum, resulting in interannual variation of seed production and germination and, consequently, of individuals able to be recruited.

In the case of the present study, this behavior may be responsible for the absence or decrease in the number of individuals: P. pyramidalis, P. stipulacea, C. flexuosa, C. oncocalyx, $A$. pyrifolium, $C$. leprosum and $X$. americanada of saplings in relation to the adult stratum of the Flona de Assu and C. leptophloeos, M. tenuiflora, P. pyramidalis, A. colubrina, C. quercifolius, A. pyrifolium at Esec do Seridó, when comparing the adult and saplings strata.

In addition, in areas with a history of anthropogenic disturbances, the combination of low seed availability, dispersal failure, low germination rates and high herbivory by domestic animals could explain lower diversity and simplification of communities, resulting in high similarity [1].

Despite the high similarity that was found between strata at both sites in this study, higher diversity adult communities result in lower strata similarity, possibly because they may provideconditions for the diversification of phenological patterns, resulting in temporal variations in the establishment of the propagules [19].

Thus, the higher diversity of the adult stratum that was recorded in the Flona de Assu may have contributed to a lower Chao-Sørensen similarity index when compared to Esec do Seridó, which had lower diversity and greater dominance in the adult stratum (Table 3).

Regarding the differences that have been found regarding diversity, we must consider that in areas with records of anthropogenic disturbances, the impacts of these actions usually favor a small group of species tolerant to the impacts of interventions, which become locally dominant [1], [50] with clear implications for diversity and dominance, as well as direct effects on the similarity between ontogenetic stages on a local scale.
However, regarding the richness, diversity and structure of the Caatinga vegetation in the Seridó region, research has shown that this region is a typology that naturally has less floristic diversity and lower biomass production when compared to other typologies of Caatinga [32], [33].

Regarding the regenerating stratum, the greater diversity in the Esec do Serido could be explained mainly by the fact that, although it presented a lower richness in relation to the Flona de Assu, the number of individuals recorded was better distributed among the sampled species. This behavior can be explained by the Simpson index, which was 0.158 in the Esec do Seridó and 0.24 in the Flona de Assu. At Flona de Assu which two species (H. impetiginosus and unidentified) were responsible for $64 \%$ of the saplings registered.

Although the diversity of saplings recorded at Esec do Seridó was greater than that of Flona de Assu, other studies have reported the deleterious effects of anthropogenic disturbance not only on the richness and floristic composition of Caatinga physiognomies, but also on functional diversity, richness and distribution of functional traits, forest structure, biomass accumulation capacity and productivity [1], [3], [5], [53], [50].

The high dominance recorded in the saplings in both analized areas can confirm that the structure of natural regeneration in both the preserved Caatinga areas and those subjected to anthropic interventions can be characterized by communities with low floristic richness and ecological dominance. The formation of clusters of dominant species is responsible for local floristic uniformity, as these species produce large amounts of seeds that adapt to specific environmental conditions, contributing to the spread of quasi-monospecific communities [14], [15], [16], [17].

However, despite strong evidence of the influence that anthropogenic disturbances have on community simplification, the high similarity between strata recorded in the Flona de Assu, an area with a conservation history for at least 50 years, favors the understanding that similarity between saplings and the adult community is a 
natural attribute in at least hyperxerophilic typologies of the Caatinga.

In the case of the studied areas, the existence of locally uniform conditions, such as precipitation regimes or the soil attributes, for example, may define environmental standards that favor the dominance of adapted groups of species.

In addition to this fact, given the great importance of water availability in tropical dry forests (TDF), tree species are expected to have a non random pattern of spatial distribution along water availability gradients, as well as differential responses of individual species [9], [10]. It is also important to highlight the importance of vegetative reproduction strategies for the perpetuation of treeshrub communities in dry tropical forests. Reproduction from the sprouting of strains or roots can trigger the availability of resources for further regeneration in these forests. In such cases, large patches that have suffered intense mortality can favor the regeneration of one or a few species [9].

In the case of Flona de Assu, this facts can be evidenced by the predominance of two families (Fabaceae and Boraginaceae), which corresponded to 11 of the registered species ( $44 \%$ of the total), of which six were common to both strata. At Esec do Seridó, Fabaceae and Euphorbiaceae were responsible for 11 species (58\% of the total), of which six were shared by the two strata.

This behavior may show that a small number of species are responsible for the key processes that structure and control the main mechanisms of existence and persistence of these ecosystems. These groups of organisms seem to direct and control the critical processes necessary for ecosystem functioning [11], [12], [13], enabling the maintenance of similar communities in terms of the composition of the adult and saplings strata.

The phytosociological characterization demonstrates that in both locations evaluated in this research, a small number of species make up a significant portion of the values of the structural parameters of the communities. In the Flona de Assu, five species $(H$. impetiginosus, $P$. pyramidalis, $B$. cheilantha, $A$. pyrifolium and $P$. stipulacea) correspond to $60 \%$ of the value of relative importance (IV $\%)$. For the relative density - DR (\%), relative dominance - DoR (\%) parameters, the pattern was similar. In turn, at Esec do Seridó, six species ( $P$. pyramidalis, $M$. tenuiflora, C. leptophloeos, C.blanchetianus, A.colubrina and A.pyrifolium) accounted for $80 \%$ of the value of importance (IV \%), $89 \%$ of relative density - DR (\%) and $91 \%$ of relative dominance - DoR (\%) (Table 4).

Thus, despite the high floristic similarity between adults and saplings, the maintenance of floristic structure, richness and diversification in accordance with the local specificities of Caatinga typologies must be a component of management and conservation strategies [1], [3], [5], especially since less abundant species need to be kept in ecosystems, as they are important for maintaining community diversification and providing indispensable and non-existent ecosystem services that are available from other species.

Theoretically, one might expect that most changes in biodiversity, in terms of species loss or dramatic reduction in abundance, would have little impact on a given ecosystem function if there are equivalent or redundant species (able to perform the same ecological functions); however, if the changes involve nonredundant or non-equivalent species, changes in ecosystem functioning may be dramatic [54].

These measures are important, since the reduction of variability, diversity and complexity, with the concomitant standardization of ecological systems, can result in a decrease in the resilience of ecological systems [55], [56].

As an example, we can mention the species that have low wood density, which are generally not valued for direct human uses (biofuel, wood or fodder). Although not abundant in Caatinga areas, they are ecologically important, because of their low density wood, they have a high water storage capacity in the stems, allowing them to bloom and fruit in the dry season, being an important source of floral and fruit resources for the local fauna during this period [6]. Thus, changes in plant functional traits associated with plant resource use are likely to affect ecosystem functioning and services provided by Caatinga [50].

\section{Conclusions and recommendations}

Contrary to the hypotheses, the evaluated data provided evidence that in areas of hyperxerophilic Caatinga, both in conserved sites and in those with a past history of anthropic interventions, there is a high floristic similarity between adult and in regeneration strata, although there is a strong qualitative discrepancy between richness, with high number of species restricted to the adult stratum in both locations. This can indicate that, at least on a local scale, not only anthropogenic disturbances are responsible for defining conditions that driver the floristic composition.

In both areas, the existence of locally uniform conditions, such as rainfall regimes or soil attributes, for example, may define environmental patterns that favor the dominance of adapted species groups and the spread 
of floristically similar forest ecosystems at the local level. Additionally, strategies of vegetative reproduction (sprouting of strains and roots) in response to human interventions or unfavorable periods can contribute to the regeneration of those species that have this capacity.

This behavior may show that a small number of species are responsible for the key processes that structure and control the main mechanisms of existence and persistence of these ecosystems.

However, in Flona de Assu, where the forest community was more diverse in terms of richness and structure, the similarity between the two strata evaluated was less. Thus, maintaining diversity must be considered in management and conservation strategies, as greater diversity favors the perpetuation of potentially more resilient communities due to the diversification of phenological patterns and their implication in temporal variations in seedling establishment.

\section{Acknowlegments}

This study was financed in part by the Coordenação de Aperfeiçoamento de Pessoal de Nível Superior - Brasil (CAPES) - Finance Code 001. We are grateful to the Chico Mendes Institute for Biodiversity Conservation (ICMBio) and to the management of the Assu National Forest and the Seridó Ecological Station for permission to carry out the work in the field.

\section{References}

[[1] E. M. S. Ribeiro, V. Arroyo-Rodríguez, B. A. Santos, M. Tabarelli, e I. R. Leal, "Chronic anthropogenic disturbance drives the biological impoverishment of the Brazilian Caatinga vegetation", J. Appl. Ecol., vol. 52, no 3, p. 611620, Mar, 2015.

[2] L. P. de Queiroz, D. Cardoso, M. F. Fernandes, e M. F. Moro, "Diversity and Evolution of Flowering Plants of the Caatinga Domain", in Caatinga, Springer International Publishing, 2017, p. 23-63.

[3] D. G. Souza, J. C. Sfair, A. S. de Paula, M. F. Barros, K. F. Rito, e M. Tabarelli, "Multiple drivers of aboveground biomass in a human-modified landscape of the Caatinga dry forest", For. Ecol. Manage., vol. 435, p. 57-65, Mar, 2019.

[4] I. R. Vieira, F. S. de Araújo, e R. B. Zandavalli, "Shrubs promote nucleation in the Brazilian semi-arid region", J. Arid Environ., vol. 92, p. 42-45, May, 2013.

[5] F. P. Marinho, G. G. Mazzochini, A. P. Manhães, W. W. Weisser, e G. Ganade, "Effects of past and present land use on vegetation cover and regeneration in a tropical dryland forest", J. Arid Environ., vol. 132, no 4, p. 26-33, Set. 2016.

[6] A. L. A. de Lima, E. V. de Sá Barretto Sampaio, C. C. de Castro, M. J. N. Rodal, A. C. D. Antonino, e A. L. de Melo, "Do the phenology and functional stem attributes of woody species allow for the identification of functional groups in the semiarid region of Brazil?", Trees - Struct. Funct., vol. 26, no 5, p. 1605-1616, May, 2012.

[7] A. P. D. Gonzaga, J. R. R. Pinto, E. L. M. Machado, e J. M. Felfili, "Similaridade florística entre estratos da vegetação em quatro Florestas Estacionais Deciduais na bacia do Rio São Francisco", Rodriguésia, vol. 64, no 1, p. 11-19, Mar, 2013.

[8] S. V. Martins, A. Miranda Neto, e T. M. Ribeiro, "Uma abordagem sobre diversidade e técnicas de restauração ecológica", in Restauração ecológica de ecossistemas degradados, Editora UFV, 2015, p. 19-36.

[9] P. Balvanera, S. Quijas, e A. Pérez-Jiménez, "Distribution Patterns of Tropical Dry Forest Trees Along a Mesoscale Water Availability Gradient", Biotropica, vol. 43, no 4, p. 414-422, Jul. 2011.

[10] S. J. Kupers, B. M. J. Engelbrecht, A. Hernández, S. J. Wright, C. Wirth, e N. Rüger, "Growth responses to soil water potential indirectly shape local species distributions of tropical forest seedlings", J. Ecol., vol. 107, no 2, p. 860 874, Nov, 2018.

[11] C. Folke, C. S. Holling, e C. Perrings, "Biological Diversity, Ecosystems, and the Human Scale", Ecol. Appl., vol. 6, no 4, p. 1018-1024, Nov, 1996.

[12] C. S. Holling, "Engineering resilience versus ecological resilience", Eng. within Ecol. constraints, National Academy of Sciences, p. 31-43, 1996.

[13] C. Folke et al., "Regime Shifts, Resilience, and Biodiversity in Ecosystem Management", Annu. Rev. Ecol. Evol. Syst., vol. 35, no 1, p. 557-581, Dec 2004.

[14] L. D. S. Alves, A. C. de Holanda, J. A. C. Wanderley, J. da S. Sousa, e P. G. de Almeida, "Regeneração Natural Em Uma Área De Caatinga Situada No Município De PombalPb - Brasil”, Rev. Verde, vol. 5, no 2, p. 152-168, Jun, 2010.

[15] S. de O. Silva et al., "Regeneração natural em um remanescente de caatinga com diferentes históricos de uso no agreste pernambucano", Rev. Arvore, vol. 36, no 3, p. 441-450, Jun, 2012.

[16] F. T. Alves Junior, R. L. C. Ferreira, J. A. A. da Silva, L. C. Marangon, e G. H. G. Cespedes, "Regeneração natural de uma área de caatinga no sertão Pernambucano, nordeste do Brasil", Cerne, vol. 19, no 2, p. 229-235, Jan, 2013.

[17] A. C. D. E. Holanda, F. Tadeu, D. Lima, B. M. Silva, R. G. Dourado, e A. R. Alves, "Estrutura da vegetação em remanescente de Caatinga com diferentes históricos de perturbação em Cajazeirinhas ( Pb )", Rev. Caatinga, vol. 28, no 4, p. 142-150, Nov, 2015.

[18] M. S. de Lucena, J. A. da Silva, e A. R. Alves, "Regeneração natural do estrato arbustivo-arbóreo em área de Caatinga na Estação Ecológica do Seridó - RN, Brasil”, Biotemas, vol. 29, no 2, p. 17, Jun, 2016. 
[19] M. S. de Lucena, J. A. da Silva, e A. R. Alves, "Estrato regenerante do componente lenhoso em área de Caatinga com diferentes usos, no Seridó potiguar", Rev. Ciências Ambient., vol. 12, no 1, p. 45, 2018.

[20] M. C. de Oliveira, J. M. Felfili, e M. C. da S. Júnior, "Comparação florístico-estrutural dos estratos adulto e de regeneração em Mata de Galeria perturbada no Distrito Federal, Brasil”, Rev. Bras. Biociências, vol. 13, no 3, p. 142-154, Aug 2015.

[21] A. L. Velloso, E. V. S. B. Sampaio, e F. G. C. Pareyn, Ecorregiões propostas para o bioma Caatinga, vol. 1. Recife: Associação Plantas do Nordeste; Instituto de Conservação Ambiental The Nature Conservancy do Brasil, 2002, p. 76 .

[22] W. Köppen, "Sistema geográfico dos climas", Editora Universitária UFPE, 1996.

[23] EMPARN - Empresa de Pesquisa Agropecuária do Rio Grande do Norte, "Monitoramento Pluviométrico dos Municípios - Média Histórica", 2020. [Online]. Available at: http://meteorologia.emparn.rn.gov.br:8181/climaRN/ medias_historicas_municipios_RN.htm. [Accessed: 10mar-2020].

[24] M. A. S. Miranda, P. B. Maracajá, D. D. Sousa, R. B. Lira, S. B. Melo, e L. B. Amorim, "a Flora Herbácea Na Flona Flona De Açú-Rn”, Agropecuária Científica No Semi-Árido, vol. 3, p. 31-43, 2007.

[25] C. C. de A. Costa, R. G. V. Camacho, I. D. de Macedo, e P. C. M. da Silva, "Análise comparativa da produção de serapilheira em fragmentos arbóreos e arbustivos em área de caatinga na Flona de açu-rn", Rev. Arvore, vol. 34, no 2, p. 259-265, Oct, 2010.

[26] EMPARN - Empresa de Pesquisa Agropecuária do Rio Grande do Norte, "Monitoramento Pluviométrico dos Municípios", 2020. [Online]. Available at: http:// meteorologia.emparn.rn.gov.br:8181/monitoramento/ monitoramento.php. [Accessed: 10-mar-2020].

[27] R. B. Lira, P. B. Maracajá, M. A. S. Miranda, D. D. Sousa, S. B. Melo, e L. B. Amorim, "Estudo da composição florística arbóreo-arbustiva na Florestal Nacional de Açu no semiárido do RN Brasil", Agropecuária Científica No SemiÁrido, vol. 03, p. 23-30, 2007.

[28] J. A. D. S. Santana, J. A. S. Santana Júnior, W. D. S. Barreto, e A. T. D. S. Ferreira, "Estrutura e distribuição espacial da vegetação da Caatinga na Estação Ecológica do Seridó, RN", Pesqui. Florest. Bras., vol. 36, no 88, p. 355-361, Dec, 2016.

[29] I. L. de Amorim, E. V. S. B. Sampaio, e E. de L. Araújo, "Flora e estrutura da vegetação arbustivo-arbórea de uma área de caatinga do Seridó, RN, Brasil", Acta Bot. Brasilica, vol. 19, no 3, p. 615-623, Feb, 2005.

[30] J. A. D. S. Santana e J. S. Souto, "Diversidade e Estrutura Fitossociológica da Caatinga na Estação Ecológica do Seridó-RN", Rev. Biol. e Ciências da Terra, vol. 6, no 2, p. 232-242, 2006.

[31] E. D. S. Jesus e A. Mattos, "Análise Espaço Temporal Da Evapotranspiração Sobre a Microrregião Do Seridó No Estado Do Rio Grande Do Norte", Holos, vol. 6, p. 22-32,
Dec, 2013.

[32] E. L. Amorim, Isaac Lucena de.; Sampaio, E. V. S. B.; ARAÚJO, "Fenologia de espécies lenhosas da Caatinga do Seridó, RN", Rev. Árvore, vol. 33, no 3, p. 491-499, Dec. 2009.

[33] T. C. e. C. da Costa, M. A. J. de Oliveira, L. J. d. O. Accioly, e F. H. B. B. da Silva, "Análise da degradação da caatinga no núcleo de desertificação do Seridó (RN/PB)", Rev. Bras. Eng. Agric. e Ambient., vol. 13, no SUPPL.0, p. 961-974, Apr, 2009.

[34] M. Silva de Lucena, A. R. Alves, e I. A. Bakke, "Parámetros estructurales de la vegetación arbóreo-arbustiva del bioma Caatinga sometida a sistemas silviculturales en la región semiárida de Brasil", Bosque, vol. 39, no 3, p. 385-395, 2018.

[35] EMBRAPA - Empresa Brasileira de Pesquisa Agropecuária, "Sistema brasileiro de classificação de solos", Embrapa, 2013, p. 353.

[36] M. S. de Lucena, A. R. Alves, e I. A. Bakke, "Composição florística, diversidade e estrutura da vegetação arbóreoarbustiva de caatinga sob sistemas silviculturais", Nativa, vol. 6, no 5, p. 506-516, May, 2018.

[37] Ministério do Meio Ambiente, "Plano de Manejo da Estação Ecológica do Seridó: Análise da Unidade de Conservação". Ministério do Meio Ambiente, 2004, p. 131.

[38] L. V. C. de A. Araújo e J. A. da Silva, "Unidade experimental estação ecológica do Seridó-RN", in Uso sustentável e conservação dos Recursos Florestais da Caatinga, Serviço Florestal Brasileiro, 2010, p. 215-228.

[39] Rede de Manejo Florestal da Caatinga - RMFC, "Protocolo de Medições de Parcelas Permanente", The Nature Conservancy do Brasil, 2005, p. 28.

[40] H. Lamprecht, "Silvicultura nos trópicos" GTZ, 1990, p. 343.

[41] F. A. Bernardes, "Sistema para Análises Estatísticas". Universidade Federal de Viçosa, 2007.

[42] J. A. D. S. Santana, F. de A. Vieira, M. V. Pacheco, e P. R. S. de Oliveira, "Padrão de distribuição e estrutura diamétrica de Caesalpinia pyramidalis Tul.(Catingueira) na Caatinga do Seridó", Rev. Biol. e Ciências da Terra, vol. 11, no 1, p. 116-122, 2011.

[43] CIENTEC - Consultoria e Desenvolvimento de Sistemas Ltda, "Mata nativa: sistema para análise fitossociológica e elaboração de planos de manejo de florestas nativas". CIENTEC 2002.

[44] THE ANGIOSPERM PHYLOGENY GROUP, "An update of the Angiosperm Phylogeny Group classification for the orders and families of flowering plants: APG III", Botanical Journal of the Linnean Society, Vol 161, no 2, October 2009, pp 105-121.

[45] Jardim Botânico do Rio de Janeiro, "Lista de espécies da Flora do Brasil", FLORA DO BRASIL, 2019. [Online]. Available at: http://floradobrasil.jorj.gov.br/. [Acessado: 11ago-2019].

[46] A. Chao, R. L. Chazdon, R. K. Colwell, e T.-J. Shen, "A 
new statistical approach for assessing similarity of species composition with incidence and abundance data", Ecol. Lett., vol. 8, no 2, p. 148-159, Dec, 2004.

[47] R. K. Colwell, "EstimateS - Statistical Estimation of Species Richness and Shared Species from Samples". University of Connecticut, Department of Ecology \& Evolutionary Biology, Storrs, 2013.

[48] Ø. HAMMER, "PAST - Paleontological Statistics". University of Oslo: Natural History Museum, Oslo, 2019.

[49] D. Mueller-Dambois e H. Ellenberg, "Aims and methods of vegetation ecology" Jonh Willey y Sons, 1974, p. 547.

[50] E. M. S. Ribeiro, M. Lohbeck, B. A. Santos, V. ArroyoRodríguez, M. Tabarelli, e I. R. Leal, "Functional diversity and composition of Caatinga woody flora are negatively impacted by chronic anthropogenic disturbance", J. Ecol., vol. 107, no 5, p. 2291-2302, Apr, 2019.

[51] D. L. M. Vieira e A. Scariot, "Principles of natural regeneration of tropical dry forests for restoration", Restor. Ecol., vol. 14, no 1, p. 11-20, Feb, 2006.

[52] R. Bhadouria, R. Singh, P. Srivastava, e A. S. Raghubanshi, "Understanding the ecology of tree-seedling growth in dry tropical environment: a management perspective", Energy, Ecol. Environ., vol. 1, no 5, p. 296-309, Aug, 2016.

[53] K. F. Rito, V. Arroyo-Rodríguez, R. T. Queiroz, I. R. Leal, e M. Tabarelli, "Precipitation mediates the effect of human disturbance on the Brazilian Caatinga vegetation", J. Ecol., vol. 105, no 3, p. 828-838, Nov, 2016.

[54] S. Naeem, "Biodiversity and ecosystem functioning in restored ecosystems: extracting principles for a synthetic perspective", in Foundations of Restoration Ecology, Island Press, 2006, p. 210-237.

[55] C. S. Holling, "Resilience and stability of ecological systems”,Annu.Rev.Ecol.Syst., vol. 4, p. 1-23, Nov, 1973.

[56] C. R. Allen, L. H. Gunderson, e C. S. Holling, "Commentary on parte on article", in Foundations of Ecological Resilience, Island Press, 2010, p. 197-204. 